\title{
Cutaneous leishmaniasis in Cavia porcellus (guinea pig): case report
}

[Leishmaniose cutânea em Cavia porcellus (cobaia): relato de caso]

\author{
L. Dalla Rosa ${ }^{1}$, A.G. Soares ${ }^{2}$, A. Marcili ${ }^{3}$, J.D.S. Diaz ${ }^{4}$, P. Wolkmer ${ }^{4}$,
}

D.M. Bassuino ${ }^{4}$, P.G.J. Schaefer ${ }^{4}$, K. Henrich ${ }^{4}$, C.K. Rossato

${ }^{1}$ Universidade Federal do Rio Grande do Sul - Porto Alegre, RS

${ }^{2}$ Instituto de Pesquisas Veterinárias Desidério Finamor - Eldorado do Sul, RS

${ }^{3}$ Universidade Santo Amaro - São Paulo, SP

${ }^{4}$ Universidade de Cruz Alta - Cruz Alta, RS

\begin{abstract}
Leishmaniasis is a parasitic disease of worldwide spread. It is caused by protozoa of the genus Leishmania and is transmitted to animals and humans through the bite of sand flies. In Brazil, leishmaniasis is one of the zoonoses of major importance and expansion. The objective of this work is to describe the clinical, pathological, immunohistochemical and molecular findings of cutaneous leishmaniasis by Leishmania enriettii in guinea pig (Cavia porcellus). Three animals had nodular and alopecia lesions on the muzzle, ears and ulcerated lesions on the distal extremities of the pelvic limbs. The males (2) also had diffuse thickening of the scrotal skin. Samples of the ulcerated cutaneous lesions were evaluated by cytology which were observed as amastigote forms of Leishmania. One of the animals was euthanized and necropsied. Histopathology showed abundant dermal infiltrate of macrophages, plasma cells, lymphocytes and multinucleated giant cells. Numerous macrophages contained parasitoid vacuoles with amastigote forms, evidenced by immunohistochemical examination. The molecular characterization based on the SSUrDNA gene identified the species as L. enrietti. The diagnosis of cutaneous leishmaniasis in these cases was based on pathological findings and confirmed by immunohistochemistry, PCR and sequencing.
\end{abstract}

Keywords: Leishmania enriettii, protozoan, zoonosis

\section{RESUMO}

A leishmaniose é uma doença parasitária de distribuição mundial. É causada por protozoários do gênero Leishmania e é transmitida para animais e seres humanos por meio da picada de flebotomíneos. No Brasil, a leishmaniose é uma das zoonoses de maior importância e expansão. O objetivo deste trabalho é descrever os achados clínicos, patológicos, imuno-histoquímicos e moleculares de leishmaniose cutânea por Leishmania enriettii em cobaia (Cavia porcellus). Três animais apresentavam lesões nodulares $e$ alopécicas no focinho e orelhas, além de lesões ulceradas nas extremidades distais dos membros pélvicos. Nos machos (2), foi observado espessamento difuso da pele escrotal. Amostras das lesões cutâneas ulceradas foram avaliadas por citologia, nas quais foram observadas formas amastigotas de Leishmania. Um dos animais foi submetido à eutanásia e necropsiado. Na histopatologia, foi observado infiltrado dérmico abundante de macrófagos, plasmócitos, linfócitos e com células gigantes multinucleadas. Numerosos macrófagos continham vacúolos parasitóforos com formas amastigotas, evidenciados por meio do exame de imuno-histoquímica. A caracterização molecular baseada no gene de SSUrDNA identificou a espécie como $\mathrm{L}$. enrietti. O diagnóstico de leishmaniose cutânea nesses casos foi baseado nos achados patológicos e confirmado pelas técnicas de imuno-histoquímica, PCR e sequenciamento.

Palavras-chave: Leishmania enriettii, protozoário, zoonose

Recebido em 11 de abril de 2019

Aceito em 30 de agosto de 2019

E-mail: lucianadallarosa@gmail.com 


\section{INTRODUCTION}

Leishmaniasis is a parasitic disease caused by protozoa of the genus Leishmania (Kinetoplastida, Trypanosomatidae) which are transmitted by sand flies. It is among the five most important zoonoses worldwide, and is considered an expanding disease in Brazil. About 53 species of the parasite have been described from different regions of the world; of these, 31 species are known to be parasites of mammals and 20 species are pathogenic for human beings (Alvar et al., 2012).

Leishmania enriettii cause natural infections of domestic guinea-pigs (Cavia porcellus) (Muniz and Medina, 1948). This species was considered an example of a noninfectious species to man (Machado et al., 1994; Paranaíba et al., 2015). The exuberant growth of amastigotes in the skin of the guinea-pig, and the ease with which the parasite is grown in simple blood-agar media, soon made the parasite a favorite model for chemotherapeutic studies (Laison, 1997). However, phylogenetic analysis showed members of the L. enriettii complex, which is emerging as new subgenus Mundinia of Leishmania parasites containing human pathogens (Kwakye-Nuako et al., 2015; Espinosa et al., 2016). The aim of the current study was to describe the clinical, pathological, immunohistochemical findings and molecular evaluation of cutaneous leishmaniasis by $L$. enriettii in guinea pigs.

\section{CASUISTRY}

Three guinea pigs (Cavia porcellus), two males and one female, with clinical history of weakness, behavioral alterations such as selfmutilation and ulcerative cutaneous lesions were attended at the Veterinary Hospital of the University of Cruz Alta. According to the owner, these animals were raised together with dozens other guinea pigs and in proximity to other animal specimens. In the anamnesis, the owner reported that he had seen similar lesions in other animals, which died about ten days later.

At the clinical examination, the animals had nodular lesions with alopecia on the muzzle, ears and ulcerated lesions on the distal extremities of the thoracic limbs (Figure 1A and 1B). All animals had internalized nodules in the abdominal region, oral mucosal pallor and severe dyspnea. The males also presented diffuse thickening of the scrotal skin. One of the males had a humid pulmonary rush and respiratory difficulty possibly associated with a large nodular lesion in the muzzle region. In the others, the physiological parameters of temperature, cardiac and respiratory rates were normal.

Samples of ulcerated cutaneous lesions were collected through Fine Needle Aspiration Cytology (CAAF), which reveal amastigote forms of Leishmania spp. (Figure 1C). Blood culture and molecular characterization of parasite mass obtained were also performed.

The most debilitated animal, due to unfavorable prognosis, was submitted to euthanasia for the necropsy. Fragments of various organs were collected and fixed in $10 \%$ formalin, routinely processed for histology and stained by hematoxylin-eosin (HE). Fragments of skin and lymph nodes were submitted to immunohistochemistry (IHC). The IHC was performed with the streptavidin-biotinperoxidase technique (LSAB-HRP, Dako Cytomation. Carpinteria, CA, USA), incubated with the polyclonal primary anti-Leishmania antibody at a dilution of 1:200 in phosphatebuffered saline (PBS) solution, and the reaction was revealed with 3'3-diaminobenzine (DAB, Sigma-Aldrich Corp. St. Louis, MO, USA.) counterstained with Harris hematoxylin.

Grossly, ulcerative nodular lesions were observed and covered by crusts in the auricular pavilion, extremities of thoracic and pelvic limbs, muzzle and scrotal sac. At cut surface, these lesions were white, firm and homogeneous. Histologically, the lesions of all affected guinea pigs were characterized by marked and diffuse dermal inflammatory infiltrate composed mainly of macrophages, plasma cells, lymphocytes with occasional multinucleated giant cells, and moderate fibroplasia. Numerous macrophages with large cytoplasm contained parasitoid vacuoles with amastigote forms compatible with Leishmania spp. (Figure 1D) were observed. The amastigote forms were characterized by an ovoid shape and $2-4 \mu \mathrm{m}$ in diameter. There were also extensive areas of necrosis and ulceration of the epithelium associated with myriad bacterial. In the lung there was marked interstitial thickening containing macrophages, lymphocytes and 
plasma cells, however, no amastigote forms were observed. Immunohistochemistry examination showed marked positive staining for Leishmania spp. in amastigotes located within the cytoplasm of macrophages (Figure 1E).

For the species identification, whole blood samples were inoculated in a biphasic culture medium suitable for the growth of Leishmania (solid phase BAB -blood agar base with $10 \%$ defibrillated ram blood and liquid phase of LIT medium - liver infusion tryptose, plus $10 \%$ fetal bovine serum and antibiotics). Promastigote forms of positive cultures were used to infect monolayers of the $\mathrm{J} 774$ peritoneal macrophage cell line in RPMI medium containing $10 \%$ bovine serum at $28^{\circ} \mathrm{C}$. $\mathrm{J} 774$ infected cells were monitored until cell lysis (7-10 days) and release of promastigote forms into the RPMI medium. An aliquot of the RPMI medium containing the promastigote forms was subjected to DNA extraction by the chloroform phenol technique. The extracted DNA was used in the Polymerase Chain Reaction (PCR), targeting a fragment of approximately 900 base pairs of the V7V8 SSUrDNA gene of trypanosomatids (Marcili et al., 2014). PCR products were submitted to $1.5 \%$ agarose gel elophosphorus staining, syber-safe (Thermofisher) and visualized in UV light transilluminator. The amplified products were purified and forwarded for sequencing and deposited in Genbank (accession number MK737948), showing high similarity (100\%) with L. enriettii previously deposited (KF041798).
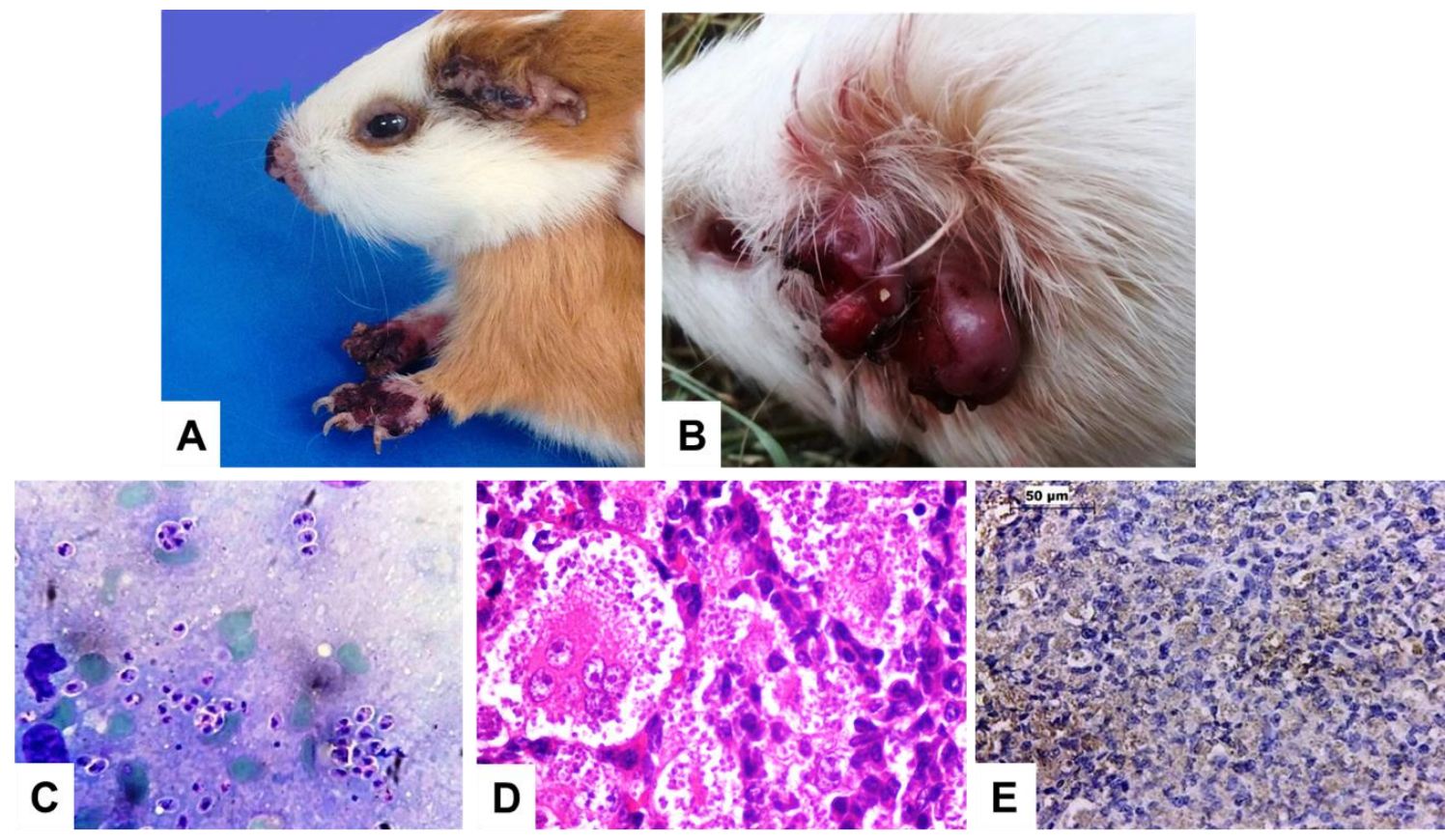

Figure 1. A) C. porcellus, ulcerative alopecia areas on the muzzle, ears and distal extremities of the thoracic limbs. B) C. porcellus, nodular and ulcerative lesions in the left auricle. C) C. porcellus, skin, amastigotes form of Leishmania spp., fine needle aspiration cytology (CAAF). HE. Obj. 40x. D) $C$. porcellus, skin, intense infiltrate of macrophages associated with large number of amastigotes, in addition to lymphocytes and plasma cells, CAAF. Obj. HE. 40x. E) C. porcellus, skin, Leishmania amastigotes in the interior of macrophages, immunohistochemistry, DAB. Obj. 20x.

\section{DISCUSSION}

Since the $L$. enriettii was discovered in $C$. porcellus in the 1940s (Muniz and Medina, 1948) several studies were published using this species as a model for human cutaneous leishmaniasis (CL). CL is a neglected tropical disease that has been significantly increasing in numbers affected over the past decades (Aronson and Joya, 2019). CL is endemic in some regions and recently areas in Thailand, Caribbean and Ghana are reporting emerging foci of L. enriettii 
complex causing human cutaneous and/or visceral infection (Paranaíba et al., 2017), confirming the high phenotypic plasticity, being able to infect different vertebrate hosts and vectors.

The first diagnostic step was clinic appearance with alopecia, raised and ulcerated cutaneous nodules and irregular thickening in the skin. Previously described cases of cutaneous leishmaniasis in guinea pigs were attributed to $L$. enriettii (Muniz and Medina, 1948; Machado et al., 1994; Lainson, 1997; Ecco et al., 2000; Fighera et al., 2003), which has an exuberant growth of its amastigote forms on the skin. Thus, the predisposition for the cutaneous development of the lesions by L. enriettii is emphasized, as the related case.

Currently, there is not a gold-standard diagnostic test; clinical practice guidelines recommend several assays using a sample from an active appearing skin lesion (Aronson and Joya, 2019). Therefore, other methodologies were realized to confirm the infection. The sensitivity of the CAAF diagnostic depends on the number of parasites in the lesion (often equates with duration) and type of lesion (ulcer often have highest yield). In the case reported, was possible the Leishmania amastigote seen is oval organism approximately 3 to $5 \mathrm{~mm}$ length, with a well circumscribed nucleus.

Other diagnostic methods used were the necropsy, tissue histopathology and immunohistochemistry aiming to review areas of well-formed necrotizing and non-necrotizing granulomas carefully. The microscopic findings included an inflammatory plasma cell and lymphocyte infiltration, fibroplasia, necrotic ulceration and large amount of amastigote forms in the cytoplasm of macrophages and were similar to those described by other authors in this same species (Ecco et al., 2000). According to Fighera et al. (2003), the mortality coefficient of this disease reaches $100 \%$ and death usually follows a clinical condition characteristic of respiratory distress due to severe bronchopneumonia, which was also observed in the guinea pig that underwent euthanasia.

\section{CONCLUSIONS}

Lastly, parasite identification has classically required parasite isolation with culture, expansion of the parasite, and nucleic acid amplification-based assays, such as PCR. In this way the infection of guinea pigs with $L$. enriettii was confirmed.

\section{REFERENCES}

ALVAR, J.; VE'LEZ, I.D.; BERN, C. et al. WHO leishmaniasis control team. Leishmaniasis worldwide and global estimates of its incidence. PLoS One, v.7, p.e35671, 2012.

ARONSON, N.E.; JOYA, C.A. Cutaneous Leishmaniasis: updates in diagnosis and management. Infect. Dis. Clin. N. Am., v.33, p.101-117, 2019.

ECCO, R.; LANGOHR, I.M.; SCHOSSLER, J.E.W. et al. Leishmaniose cutânea em cobaias (Cavia porcellus). Ciênc. Rural, v.30, p.525-528, 2000.

ESPINOSA, O.A.; SERRANO, M.G.; CAMARGO, E.P. et al. An appraisal of the taxonomy and nomenclature of trypanosomatids presently classified as Leishmania and Endotrypanum. Parasitology, v.15, p.1-13, 2016.

FIGHERA, R.A.; SOUZA, T.M.; SCHMIDT, C.A. et al. Leishmaniose mucocutânea em cobaios (Cavia porcellus). Medvep Rev. Cient. Med. Vet. Pequenos Anim. Anim. Estim., v.1, p.177-182, 2003.

KWAKYE-NUAKO, G.; MOSORE, M.T.; SUPLESSIS, C. et al. First isolation of a new species of Leishmania responsible for human cutaneous leishmaniasis in Ghana and classification in the Leishmania enriettii complex. Int. J. Parasitol., v.45, p.679-684, 2015.

LAINSON, R. On Leishmania enriettii and Other Enigmatic Leishmania Species of the Neotropics. Mem. Inst. Oswaldo Cruz, v.92, p.377-387, 1997.

MACHADO, M.I.; MILDER, R.V.; PACHECO, R.S. et al. Naturally acquired infections with Leishmania enrietti Muniz and Medina 1948 in guinea-pigs from São Paulo, Brazil. Parasitology, v.109, p.135-138, 1994. 
MARCILI, A.; SPERANÇA, M.A.; DA COSTA, A.P. et al. Phylogenetic relationships of Leishmania species based on trypanosomatid barcode (SSU rDNA) and gGAPDH genes: Taxonomic revision of Leishmania (L.) infantum chagasi in South America. Infect. Genet. Evol., v.25, p.44-51, 2014.

MARCILI, A.; SPERANÇA, M.A.; DA COSTA, A.P. et al. Phylogenetic relationships of Leishmania species based on trypanosomatid barcode (SSU rDNA) and gGAPDH genes: Taxonomic revision of Leishmania (L.) infantum chagasi in South America. Infect. Genet. Evol., v.25, p.44-51, 2014.
MUNIZ, J.; MEDINA, H.S. Leishmaniose tegumentar do cobaio (Leishmania enriettii). Hospital, v.33, p.7-25, 1948.

PARANAÍBA, L.F.; ASSIS, R.R.; NOGUEIRA, P.M. et al. Leishmania enriettii: biochemical characterisation of lipophosphoglycans (LPGs) and glycoinositolphospholipids (GIPLs) and infectivity to Cavia porcellus. Parasite Vector, v.8, p.1-14, 2015.

PARANAÍBA, L.F.; PINHEIRO, L.J.; TORRECILHAS, A.C. et al. Leishmania enriettii (Muniz \& Medina, 1948): a highly diverse parasite is here to stay. PLoS Pathog, v.13, p.e1006303, 2017. 